\title{
Teacher, Student, Ticket: \\ John Frank, Leon Higginbotham, and \\ One Afternoon at the Supreme Court- Not a Trifling Thing
}

\author{
John Q. Barrett ${ }^{\dagger}$
}

\section{TEACHER}

A path to greatness often begins with a special teacher, and this is such a story. In the fall of 1949, John P. Frank was a new associate professor at the Yale Law School. He previously had earned undergraduate and law degrees at the University of Wisconsin, clerked at the Supreme Court for Justice Hugo L. Black during the October 1942 Term, practiced law, earned a J.S.D. degree at Yale and begun teaching law at Indiana University.

John Frank was a major constitutional law scholar by the time he joined the Yale law faculty in fall 1949. In 1947, Frank had begun publishing in the University of Chicago Law Review his extensive, interestingly opinionated, and sometimes even spicy, annual reports on the Supreme Court's just-completed Term. ${ }^{1}$ Frank had, in 1948, published a biographical sketch of Justice Black along with a compilation of his leading opinions from his first ten years on the Court. ${ }^{2}$ Frank also was the author of numerous articles on topics in constitu-

$\dagger$ Professor of Law, St. John's University School of Law. This article is dedicated to the memory of Judge A. Leon Higginbotham, Jr., who first told me the striking story that is the genesis of this article during the two years (1986-88) when I was one of his law clerks at the United States Court of Appeals for the Third Circuit in Philadelphia. I also am very grateful to Howard Buschman, Judge Robert Carter, Warren Christopher, Gloria Cole, John Frank, Isaac Groner, Jeanne Foster Higginbotham, Keith Mann, Bayless Manning, Will Maslow, Judge Louis Pollak, Charles Reich, Emest Rubenstein, Art Seder, Murray Schwartz, Larry Taylor, George Treister, Judge Patricia Wald, and Frank Wozencraft, Jr., for generously sharing their recollections, ideas, and contacts, to Jonathan Entin for very helpful comments, to Dean Anthony Kronman for providing key Yale information, and to Jonathan Bardavid, Arundhati Satkalmi, Brian Stiglmeier, and Barbara Traub for extremely capable assistance with various aspects of my research.

1. See John P. Frank, The United States Supreme Court: 1946-47, 15 U. CHI. L. REV. 1 (1947); John P. Frank, The United States Supreme Court: 1947-48, 16 U. CHI. L. REV. 1 (1948). This series continued for five more years after Frank moved from Indiana to Yale. See John P. Frank, The United States Supreme Court: 1948-49, 17 U. CHI. L. REV. 1 (1949); John P. Frank, The United States Supreme Court: 1949-50, 18 U. CHI. L. REV. 1 (1950); John P. Frank, The United States Supreme Court: 1950-51, 19 U. CHI. L. REV. 165 (1951); John P. Frank, The United States Supreme Court: 1951-52, 20 U. CHI. L. REV. 1 (1952); John P. Frank, Fred Vinson and the Chief Justiceship, 21 U. CHI. L. REV. 212 (1954). For an amusing excerpt from Frank's article on the Court's October 1949 Term, see infra note 17.

2. John P. Frank, Mr. Justice Black: The MaN ANd His OpINIONS (1949). More recently, Mr. 
tional law and history. ${ }^{3}$

Professor Frank also was, in this period, studying the law and history of race in America ${ }^{4}$ and assisting the NAACP Legal Defense and Education Fund, Inc. in anti-discrimination and desegregation cases. ${ }^{5}$ One of its leading cases at the time was Sweatt v. Painter, a constitutional attack on Texas's whites-only, and then its Jim Crow, system of public legal education. ${ }^{6}$ The NAACP had, by fall 1948, lost the Sweatt case at trial and in the Texas appellate courts and was preparing to seek review in the Supreme Court of the United States.

In conjunction with the NAACP's preparation of its petition seeking a writ of certiorari in Sweatt v. Painter, Director-Counsel Thurgood Marshall asked Yale Law School Professor Thomas I. Emerson and Indiana law professor John Frank-who within months would be Yale faculty colleagues-to draft a law professors' amicus brief. ${ }^{7}$ Emerson and Frank did the drafting and recruited a significant group of leading legal academics to sign on. When the NAACP filed its petition for certiorari on March 23, 1949, it was accompanied by a supporting brief that Emerson, Frank, and others filed on behalf of a coalition

Frank published a memoir drawn from his correspondence with Justice Black and Frank's notes of their conversations. JoHN P. FRANK, INSIDE JUSTICE HUGO L. BLACK: THE LETTERS (2000).

3. E.g., John P. Frank, Disqualification of Judges, 56 Yale L.J. 605 (1947); John P. Frank, Historical Bases of the Federal Judicial System, 13 LAW \& CONTEMP. PROBS. 3 (1948), reprinted in 23 IND. L.J. 236 (1948). See generally JOHN P. FRANK, CASES \& MATERIALS ON CONSTITUTIONAL LAW (1950) (a law school casebook); JOHN P. FRANK, CASES ON THE CONSTITUTION (1951) (a casebook for political science students). Frank's 1950 constitutional law casebook was described decades later as "magisterial" and "stellar"-it "reflected a greater respect for historical context than any law professor [in that time] had shown." LAURA KalmaN, LeGal REALISM AT YALE, 1927-1960 192, 195 (1986).

4. E.g., John P. Frank \& Robert F. Munro, The Original Understanding of "Equal Protection of the Laws", 50 COLUM. L. REV. 131 (1950). This article appeared in the "February" issue, which actually was published early in April 1950.

5. See Jonathan Entin, Bound for Distinction, APplEton (WI) Post-Crescent, View Mag., May 13, 1979, at 3, 4. See generally John P. Frank, Can Courts Erase the Color Line?, 21 J. NEGRo ED. 304 (1952), reprinted in 2 BUFF. L. REV. 28 (1952) (transcribing Professor Frank's April 17, 1952, address, which preceded Thurgood Marshall's own remarks, at Howard University's National Conference on The Courts and Racial Integration in Education, Rankin Chapel, Washington, D.C.).

6. For a comprehensive history and analysis of the litigation, briefing and Supreme Court decision, see Jonathan L. Entin, Sweatt v. Painter, the End of Segregation, and the Transformation of Education Law, 5 REV. LiTigation 3 (1986). For research archives on Sweatt v. Painter, see the Web sites of the Tarlton Law Library at the University of Texas, at http://www.law.utexas.edu/rare/sweatt.htm (visited Mar. 22, 2002), and of Professor Thomas D. Russell of the University of Denver College of Law, at http://www.law.du.edu/russell/h/sweatt (visited Mar. 22, 2002) [hereinafter Russell On-line Archive].

7. John Frank was, at this time, a friend of the dean of the all-white, segregated by law University of Texas Law School. Apparently feeling awkward about his involvement in the Sweatt litigation (in which the dean had been a trial witness) and attempting to defuse the situation with humor, Frank wrote a letter explaining that he was "cast at the moment in the role of damn Yankee trouble maker" because he had signed the brief supporting the NAACP against the University. Letter from John P. Frank to Charles McCormick, Dean, University of Texas Law School (Apr. 5, 1949), available at Russell Online Archive, supra note 6. "Please don't bother to acknowledge this letter," Frank wrote to the Dean. "I merely wanted you to hear directly from me that I was participating in the matter, rather than get it in some roundabout fashion. ..." Id. The Dean's reply was mostly gracious: "I am interested to know that you have tossed a brief into the ring in the Sweatt case. This is a free fight and anybody is welcome. 1 have practiced law too long to feel any hostility to the lawyer on the other side, bad "cess to him." Letter from Charles T. McCormick, Dean, University of Texas Law School, to John P. Frank (Apr. 8, 1949), available at Russell On-line Archive, supra note 6. 
of fifty-two leading law professors. ${ }^{8}$

In early November 1949, the Court granted certiorari in Sweatt v. Painter. ${ }^{9}$

Professors Emerson, Frank, et al. subsequently filed the now-famous amicus brief of the Committee of Law Teachers Against Segregation in Legal Education. $^{10}$ In this brief, 189 law professors ${ }^{11}$ supported the NAACP's petition, attacked the constitutional validity of the "separate but equal" doctrine of Plessy v. Ferguson, ${ }^{12}$ and told the Court-much more directly than the NAACP had in its petition for certiorari and would later in its brief on the merits ${ }^{13}$ - that segregation was the Court's mistake and one that it should correct promptly. ${ }^{14}$

\section{STUDENT}

This story also involves a young student. In autumn 1949, A. Leon Higgin-

8. The Committee's brief initially was filed in typescript. John Frank then supervised the process of getting the brief printed and filed in place of the typescript version. The brief was filed on May 9 , 1949. Motion \& Brief of Amicus Curiae in Support of Petition for Certiorari, Sweatt v. Painter, 338 U.S. 865 (1949) (No. 44). The brief explained that "[m]embership in the Committee ha[d] for some time been restricted to one or two members of each of several law school faculties in addition to those directly responsible for the brief." $I d$. at 2 .

9. 338 U.S. 865 (1949) (granting petition for writ of certiorari and noting briefs of amici, including the Committee of Law Teachers Against Segregation in Legal Education, that had been filed in support of the petition).

10. Brief of Amici Curiae in Support of Petitioner, Sweatt v. Painter, 339 U.S. 629 (1950) (No. 44). This brief was filed on January 20, 1950. See generally John P. Frank, Tom Emerson: The Constructive Advocate, 38 CASE W. RES. L. REV. 537, 537-38 (1988) (describing the Sweatt amicus brief as his and Emerson's "most intensely shared moment of joint effort"-"it was a chance to work with Tom in one of the many causes dear to his heart"). In addition to Emerson and Frank, the brief was filed by Professor Alexander H. Frey of the University of Pennsylvania Law School, Dean Erwin N. Griswold of Harvard Law School, Professor Robert Hale of Columbia University Law School, Dean Harold Havighurst of Northwestem University School of Law, and Professor Edward Levi of the University of Chicago School of Law.

11. The brief explained that " $t]$ he Committee... was formed for the purpose of expressing the conviction of many law teachers that segregation in legal education is unconstitutional." Brief of Amici Curiae in Support of Petitioner, Sweatt v. Painter, supra note 10, at 49 Appendix A (listing the 189 members of the Committee). Cf. Supplement to Brief of Amici Curiae, Sweatt (No. 44). The supplement was filed on April 4, 1950 and added to the record before the Court the minutes of the December 29, 1949, meeting at which the Association of American Law Schools had deferred acting on the Texas State University for Negroes School of Law's application for AALS membership. Id.

12. 163 U.S. 537 (1896).

13. See Brief of Petitioners, Sweatt (No. 44). This brief was filed on February 27, 1950.

14. See Segregation and the Equal Protection Clause, 34 MINN. L. REV. 289 (1950) (publishing much of the amicus brief shortly before Sweatt was argued in the Supreme Court). See also Entin, supra note 6, at 42-56 (summarizing and comparing the arguments in Sweatt of the NAACP, the Law Teachers, the State of Texas, and the United States Government); Dennis. J. Hutchinson, Unanimity and Desegregation: Decisionmaking in the Supreme Court, 1948-1958, 68 GEO. L.J. 1, 17-18 (1979) (describing the differing tacks taken by the parties and amici in Sweatt and its companion cases). For the names of the 189 members of the Committee of Law Teachers Against Segregation in Legal Education, see Segregation and the Equal Protection Clause at 328-29.

The Supreme Court's filing fees for the Committee's amicus briefs ultimately totaled $\$ 21.55$. See Letter from Thomas I. Emerson, Professor of Law, to Charles Elmore Cropley, Office of the Clerk (Aug. 2,1950 ) (enclosing check) (copy on file with author). For discussions of this brief and its place in the NAACP litigation campaign against segregation, see RICHARD KLUGER, SIMPLE JUSTICE: THE HISTORY OF BROWN V. BOARD OF EDUCATION AND BLACK AMERICA'S STRUGGLE FOR EQUALITY 274-76 (1975), and Jonathan L. Entin, The Law Professor as Advocate, 38 CASE W. RES. L. REV. 512, 519-22 (1988). 
botham, Jr., was a first year law student at Yale. Higginbotham, a 21-year-old black man from Trenton, New Jersey, had attended Purdue University and, after transferring, graduated from Antioch College in 1949.

Leon Higginbotham was one of three black students who entered Yale Law School in fall 1949. Higginbotham met John Frank when he (ALH) was assigned to take Frank's "Procedure I" course. Higginbotham, who had what Frank later described as "an extraordinary verbal talent," 15 quickly impressed his professor in class, and they became acquainted outside the classroom. Higginbotham started to work for Frank as a research assistant and they became friends. ${ }^{16}$

\section{TICKET}

This story also involves an excursion. In early 1950, the Supreme Court scheduled three segregation cases, including Sweatt v. Painter, for oral argument. ${ }^{17}$ Professor John Frank, who of course was deeply interested in Sweatt and this litigation generally, decided to attend the oral argument.

Although the cases mattered greatly to John Frank, visiting the Supreme Court of the United States was, to him, no big deal. Frank had worked there as a law clerk. He had, by spring 1950, returned there regularly to hear arguments or just to visit friends (with Justice Black heading that list). The Supreme Court was, in other words, well within John Frank's horizon-it was part of the realm in which he, as a citizen, lawyer, thinker, and scholar, comfortably traveled and

15. John P. Frank, Giant: A Higginbotham Memoir, 142 U. PA. L. REV. 521,524 (1993).

16. See id. at 523 . Yale paid Higginbotham $\$ 1.50$ per hour for this research work on an early stage of what became John Frank's biography of Justice Daniel, who served on the Supreme Court from 1841 until his death in 1860. Id. See generally JOHN P. FRANK, JUSTICE DANIEL DISSENTING: A BIOGRAPHY OF PETER V. DANIEL, 1784-1860 (1964).

17. The other cases were Henderson v. United States, 339 U.S. 816 (1950) (No. 25), and McLaurin v. Oklahoma State Regents, 339 U.S. 637 (1950) (No. 34). These oral arguments initially were scheduled and then repeatedly were rescheduled to occur earlier in the Term, but the Court kept postponing them until Justice Douglas, who had been badly injured in a horse riding accident in the State of Washington on October 2, 1949, and spent the next months hospitalized and then convalescing in the west, was back in Washington, D.C. and on the Court bench. Telephone Interview with Warren M. Christopher, O.T. 1949 Law Clerk to Justice William O. Douglas (Feb. 4, 2002). See also Letters from Charles Cropley, Office of the Clerk, to various Counsel of Record (Nov. 22, 1950-Apr. 24, 1950) (informing counsel that oral argument was scheduled for the week of January 3, 1950, then the week of March 13,1950, then the day March 20,1950, and then finally the week of April 3, 1950) (copies on file with author). See generally WILlIAM O. DOUGLAS, Go EAST, YOUNG MAN 198-200 (1974) (describing the accident and his injuries); JAMES F. SIMON, INDEPENDENT JOURNEY: THE LIFE OF WILLIAM $O$. DOUGLAS 281-84 (1980) (describing the accident and Douglas's months away from the Court during the October 1949 Term).

In his scholarly recap on the October 1949 Term, John Frank included an entertaining comment on Justice Douglas's health and other pursuits:

Due to a serious riding mishap, Justice Douglas was unable to rejoin the Court until Spring.

During his recuperation he published a best seller on his mountain climbing experiences and in the Spring he was chosen most unwillingly "father of the year." By the Summer of 1950 he was sufficiently recovered to be able to undertake a new mountain climbing excursion in Iran.

Frank, The United States Supreme Court: 1949-50, supra note 1, at 46. 
operated.

John Frank's 1950 trip to the Court was not, however, a solo excursion. He invited Leon Higginbotham to come with him to Washington to see and hear the Sweatt v. Painter argument. ${ }^{18}$

The Supreme Court was not, to understate the matter grossly, within Leon Higginbotham's horizon even by the spring of 1950 . He was, to be sure, a student at one of the country's very best law schools. But he was black, he was poor, and he was not well traveled. Raised in the poverty and segregation of Trenton, Higginbotham had not, it seems, ever been to Washington, and he certainly had never set foot in the highest court in the land. Now, thanks to Professor John Frank, that would change.

John Frank made arrangements for Higginbotham to get into the Court by telephoning Justice Black. Frank told his former boss that he would like one of his students to have the opportunity to hear the Sweatt $v$. Painter arguments and Justice Black made the arrangements. Frank also bought Higginbotham, who had no spare funds for such things, ${ }^{19}$ the train ticket that got him from New Haven to Washington and back on this occasion.

When Higginbotham arrived at the Supreme Court on Tuesday, April 4,

18. In the text that follows, my account of Leon Higginbotham's April 1950 trip to the Supreme Court is compiled from five reports of his recollections of that day. They are: (1) his 1991 essay on the occasion of Justice Thurgood Marshall's retirement from the Supreme Court, A. Leon Higginbotham, Jr., A Tribute to Justice Thurgood Marshall, 105 HARV. L. REV. 55, 60 \& nn.32-33 [hereinafter ALH 1991 Marshall Tribute]; (2) Judge Higginbotham's June 1993 impromptu remarks at the Alliance for Justice's annual Law Day luncheon, Memorandum from Nan Aron to Friends of the Alliance (July 7, 1993) (copy on file with author) [hereinafter ALH 1993 Alliance for Justice remarks]; (3) Higginbotham's remarks during a 1995 newspaper interview, Mark Feeny, Off the Bench But Still in the Arena, Boston GloBE, May 21, 1995, at 47; (4) Judge Higginbotham's May 7, 1996, speech in the Supreme Court, A. Leon Higginbotham, Jr., Justice Thurgood Marshall: He Knew the Anguish of the Silenced and Gave Them a Voice, 3 GEO. J. ON FIGHTING POVERTY 163, 165 (1996); and (5) an early 1998 newspaper essay, A. Leon Higginbotham, Jr., Breaking Thurgood Marshall's Promise, N.Y. TIMES MAG., Jan. 18, 1998, at 28. As a law clerk to Jugdge Higginbotham in the mid-1980s, I and coclerks regularly got to hear the Judge mention, and sometimes he recounted at length, his memories of that day in April 1950. I know that many other students, colleagues and friends of the Judge had similar experiences with him. See, e.g., Entin, supra note 6, at 3 (footnoting thanks to Judge Higginbotham for supporting and encouraging the author's comprehensive historical study of the Sweatt case). To my great regret, I did not make notes of those conversations, nor did I ever interview the Judge to get his full account.

19. Leon Higginbotham attended Yale Law School on a tuition scholarship from the Jessie Smith Noyes Foundation. In his first two years in New Haven, Higginbotham (and, during the second year, his wife Jeanne) lived at 258 Starr Street, in a "black neighborhood" more than a mile from school, because he could not afford to live on campus. Telephone Interview with Jeanne Foster Higginbotham (Mar. 26, 2002). See generally A. Leon Higginbotham, Jr., The Dream with Its Back against the Wall, 46 YALE L. REPORT 24, 27 (1999). At this address, he rented a single room on the second floor of a house and shared a hallway bathroom with another tenant couple. His meals included leftover hamburger meat"sometimes it was brown, sometimes it was gray"- - that the proprietor of his comer store gave him at closing time each Saturday night. Id. Although 258 Starr Street is now a vacant lot, the store at the corner of Start Street and Shelton Avenue still stands. The neighborhood's very modest and not wellmaintained housing stock is older wood-frame houses, many of which are divided into apartments, and newer rowhouses and small apartment buildings. On February 24,2002 , which was a mild and sunny Sunday afternoon, numerous people were out and about in the neighborhood, and none was white. 
1950, he noticed the "huge waiting line" of people who were hoping to obtain a courtroom seat in the general public section. By spring 1950, the public generally was very interested in the Supreme Court and in the segregation cases it was hearing and preparing to decide. On that April 4th, public interest may have been particularly high because the previous day had seen Attorney General J. Howard McGrath and Solicitor General Philip B. Perlman each argue to the Court that it should reverse the 54-year-old doctrine of Plessy $v$. Ferguson. ${ }^{20}$ Higginbotham realized that, without John Frank's help, he never would have gotten a seat in the courtroom.

Higginbotham sat in the courtroom with Justice Black's law clerk, ${ }^{21}$ other law clerks, the Justices' family members and friends, and members of the Supreme Court bar.

At noon, the Justices took the bench. They were, from Higginbotham's left to right view, Tom Clark, Robert Jackson, Felix Frankfurter, Hugo Black, Fred Vinson, Stanley Reed, William O. Douglas, Harold Burton, and Sherman Minton. (These eight Associate Justices were, it should be noted, the men who would, only four years later, join unanimously in the next Chief Justice's opinion for the Court in Brown v. Board of Education. ${ }^{22}$ )

On that April afternoon-and Leon Higginbotham seems to have been present for all of the day's proceedings ${ }^{23}$ - the Justices first admitted eleven attor-

20. See Chalmers M. Roberts, 'Separate But Equal' Doctrine Hit, WASH. PoST, Apr. 4, 1950, at 1, 13 (describing "an atmosphere of history-in-the-making. . . It appeared the audience [that witnessed the oral arguments in Henderson v. United States, No. 25] sensed it was sitting in on a case the like of which the court had not seen since the days of Dred Scott some 93 years ago."). See also Lewis Wood, Bar Segregation, High Court Asked, N.Y. TIMES, Apr. 4, 1950, at 58; McGrath Asks Supreme Court To Place Ban on Segregation, WASH. TIMES-HERALD, Apr. 4, 1950, at 2 (quoting from McGrath's oral argument). In Henderson's companion cases, McLaurin v. Oklahoma State Regents and Sweatt $v$. Painter, the Department of Justice participated for the first time in legal attacks on school segregation. MARY L. Dudziak, COLD WAR CIVIL RightS: RACE \& THE IMAGE OF AMERICAN DEMOCRACY 94 (2000).

21. Justice Black's law clerk during the October 1949 Term clerk was Frank McReynolds Wozencraft (1923-1994), a Dallas, Texas, native who had graduated from Yale Law School in June 1949 after serving as Editor-in-Chief of the Yale Law Journal. Wozencraft later became an associate and then partner at the Baker \& Botts law firm in Houston, served as Assistant Attomey General heading the Office of Legal Counsel in the United States Department of Justice from 1966-69 and was vice chair of the Administrative Conference of the United States from 1968-71. He also held various leadership positions in the American Bar Association.

22. 347 U.S. 483 (1954).

23. Judge Higginbotham consistently described having been present on the day that Sweatt was argued. It thus seems likely that he was present for the second half of the McLaurin oral argument, which had begun on the previous day and was completed immediately prior to the $S$ weatt argument. It seems less likely that Higginbotham was present for the Henderson argument, which occurred on April 3, 1950, immediately prior to the start of the McLaurin argument. Judge Higginbotham's statement in a footnote that he heard the oral arguments in both Henderson and McLaurin on the same day that he heard the arguments in Sweatt, see ALH 1991 Marshall Tribute, supra note 18, at $60 \mathrm{n.33}$, thus seems to be a recollection that was only two-thirds accurate. Cf. John P. Frank, The United States Supreme Court: 1949-50, supra note 1, at 34 (writing that Attorney General McGrath "is said to have presented a powerful and effective" argument in Henderson - a hearsay formulation that would not have been necessary if Frank had been present, with Higginbotham, to hear McGrath's argument on April 3, 1950). 
neys to the Court's bar. ${ }^{24}$

The Justices then heard the completion of oral argument in McLaurin $v$. Oklahoma State Regents, the argument that had been in progress when the Court had recessed the previous afternoon. ${ }^{25}$ G.W. McLaurin, who was black, was a professor at Langston University. He already held a master's degree and was taking doctoral courses in education at the University of Oklahoma. $\mathrm{He}$ was, as the case had evolved by this point in time, bringing an equal protection challenge to the University requirements that he sit in a separate "colored student" seat in the classroom and at separate tables in the library and cafeteria.

NAACP attorney Robert L. Carter, representing McLaurin, argued first. ${ }^{26}$ Carter, fielding numerous questions from the Justices, explained exactly how McLaurin was being treated at the University. Carter explained that, although there had been factual changes in such things as McLaurin's classroom seating over the course of the litigation, Negro students like McLaurin still were being segregated based on race, and that any segregation violated the Fourteenth Amendment. ${ }^{27}$ Carter then turned to Plessy, arguing that it was wrong as a reading of the Equal Protection Clause and, as a decision in the context of transportation, also entirely inapplicable in the education context. ${ }^{28}$

Fred Hansen, Oklahoma's First Assistant Attorney General, argued for the State. He asserted that state school officials-"thoughtful men and good men"-were doing the best they could to deal with a true dilemma: state law required them to provide segregated education for Negroes, but the legislature had refused to provide funds to construct adequate separate school facilities for Negroes. The officials accordingly had devised the procedures by which McLaurin was receiving instruction at, but being segregated within, the University of Oklahoma. This policy, Hansen admitted under a barrage of questions from the Justices, was "unwritten." Going further, he admitted that the breakdown of true segregation at the University of Oklahoma "possibly" showed that there was not much point to it "on the graduate's level." Hansen nonetheless

24. Supreme Court of The UnITED States, Journal of THE COURT at 173 (Apr. 4, 1950).

25. During this period, oral arguments before the Court were not tape-recorded or officially transcribed. One contemporaneous document reports that "the Attomey General of Texas had the [Sweatt] arguments reported. ..." Letter from E.P. Cullinan, Assistant to Supreme Court Clerk Charles Elmore Cropley, to Helen Hargrave, Law Librarian, Univ. of Texas Law Library (Apr. 24, 1950) (copy on file with author). I have been unable to locate any such report. My descriptions in the text of the McLaurin and Sweatt oral arguments are, accordingly, based on the press accounts, American Jewish Congress memorandum, and personal recollections that I have quoted from and cited.

26. Amos T. Hall, who also represented McLaurin — and was, like Carter and their client, blackhad presented his argument to the Court the previous afternoon. SUPREME COURT OF THE UNITED STATES, JOURNAL OF THE COURT 172 (Apr. 3, 1950). Robert Carter had then begun his presentation, arguing for about fifteen minutes, without interruption, until the Court recessed for the day. On the next day, Carter completed his argument amidst active questioning by the Justices. Letter from the Honorable Robert L. Carter to author, Apr. 10, 2002 (copy on file with author).

27. Chalmers M. Roberts, Graduate Schools' Segregation at Issue, WASH. PoST, Apr. 5, 1950, at 6.

28. Racial "Segregation" Attacked, 18 U.S.L.W. 3277, 3278-80 (Apr. 11, 1950). 
claimed that Oklahoma "might have had trouble" if the State had not segregated students like McLaurin. Hansen defended-indeed, he read to the Court from the majority opinion in-Plessy, and he asked the Court not to discard it. Integration, he predicted, would cause Oklahoma's colored public schools to close and, as their students enrolled in the previously "white" (i.e., more expensive) schools, cause financial hardship for the State. ${ }^{29}$

Robert Carter, in rebuttal, argued that the equal treatment that McLaurin sought was more important than any state financial consideration. Carter also noted his adversary's concession that graduate school segregation was unnecessary: "That is our case.",30

The Justices then called Sweatt $v$. Painter for oral argument. Heman Marion ("Bill") Sweatt, a Negro, was a 37-year-old World War II veteran who had become a mail carrier. He had applied to the University of Texas law school but had been rejected because Negroes were, by law, barred from attending the school. The University president had subsequently offered to enroll Sweatt in a new law school, the Texas State University for Negroes, which was being built in Houston. ${ }^{31}$ During the construction year, this unaccredited black law school, located in the ground floor of a residential building near the state capitol in Austin, served two students. ${ }^{32}$ Sweatt had refused to accept a seat in this Jim Crow law school, and he sought a Supreme Court ruling that his exclusion from the University of Texas School of Law was an unconstitutional denial of equal protection. $^{33}$

Attorney W.J. Durham of Texas, a black man, began the argument on Sweatt's behalf. He described the complicated lower court history of the case and the appellate review that had preceded its arrival in the Supreme Court. ${ }^{34}$

Following Durham's argument, the Court heard from Thurgood Marshall. Although he was only 41 years old, Sweatt $v$. Painter was the eighth case in which Marshall argued before the Court. Marshall told the Justices that Sweatt's case had been, from its inception, an attack on "separate but equal" legal education: "we've been 30 years trying to get this issue before this court." "They can build an exact duplicate of the University of Texas Law School," Marshall stated, "but if it is segregated, it is unequal" and Sweatt will,

29. Id.

30. Id.

31. In 1951, the Texas State University for Negroes became Texas Southem University. In 1976, its law school was officially dedicated the Thurgood Marshall School of Law. For Justice Marshall's stirring remarks on this occasion, see Address by the Honorable Thurgood Marshall, 4 TEXAS So. L. REV. 191 (1976-77).

32. Oral history interview of Prof. Corwin W. Johnson, Nov. 15, 1996, available at Rusell on-line archive, supra note 6.

33. For the complicated history of the Sweat litigation, see MARK V. TUSHNET, THE NAACP'S Legal Strategy AGaINST Segregated EduCATION, 1925-1950 126-30 (1987).

34. Racial "Segregation" Attacked, 18 U.S.L.W. 3277, 3280 (Apr. 11, 1950).

35. Roberts, supra note 27 , at 6 . 
as he had testified at trial, refuse to attend. ${ }^{36}$ The problem, Marshall told the Justices, was Plessy v. Ferguson, which was inconsistent with subsequent Court decisions that had identified racial classifications as odious.

As Leon Higginbotham recalled it many years later, Marshall also explained in a uniquely effective manner why segregated legal education was doomed to remain permanently unequal:

Thurgood Marshall ... was then young, in his early 40s. And he stated to the Court, "How can it be that this law school, which does not have any alumni, can be equivalent to the University of Texas, which has so many members in the State House of Representatives, so many members in the State Senate"-And then he paused. It seemed like he stood before the podium for a full minute, and he said"including one Justice"-looking directly at Tom Clark from the University of Texas-"who sits on this Court?"37

Marshall implored the Justices not to give in to baseless threats that integration would produce lawlessness. The demise of the "white primary" and the start of Negro voting ${ }^{38}$ had not, Marshall noted, produced trouble. Marshall also noted that Sweatt's case was about only one qualified Negro applicant's right to attend his state's best law school; it was not a request for common schools or integrated swimming pools. And, Marshall predicted, white law students would not behave like hoodlums if Sweatt were to be admitted as their colleague. $^{39}$

Following Marshall's argument, the Court heard from the Attorney General of Texas, Price Daniel. ${ }^{40}$ As Higginbotham recalled years later:

[Daniel's] fascinating ... argument proceeded somewhat like this: "Now your honors, the 14th Amendment prohibits adverse discrimination, but there is nothing in the 14th Amendment that says if a Nigra is treated better than anyone else, that there is a constitutional violation. And this is a matter of social policy and not a matter of constitutional doctrine, which my adversaries would like. Now look at Sweatt, he's getting the best education in America. He's the only person in his

36. Racial "Segregation" Attacked, supra note 34.

37. ALH 1993 Alliance for Justice remarks, supra note 18, at 2. Justice Clark, who earned both his undergraduate (1921) and law (1922) degrees from the University of Texas, was, in April 1950, completing his first Term as an Associate Justice.

38. See Smith v. Allwright, 321 U.S. 649 (1944). The Smith case, which was first argued in November 1943, was Thurgood Marshall's first oral argument before the Supreme Court. For a history of the NAACP and other litigation that culminated in this decision, see MARK V. TUSHNET, MAKING CIVIL RIGHTS LAW: THURGOOD MARSHALL AND THE SUPREME COURT, 1936-1961 99-107 (1994).

39. Racial "Segregation" Attacked, 18 U.S.L.W. 3277, 3280 (Apr. 11, 1950).

40. Marion Price Daniel, Sr. (1910-1988), formerly a state legislator and speaker of the Texas House of Representatives, was elected Attorney General and served for six years. In 1952, he was elected to the United States Senate. In 1956, he ran for Governor of Texas, was elected and resigned from the Senate on inauguration to his new office. Governor Daniel was reelected in 1958 and 1960 but was defeated when he sought an unprecedented fourth term in 1962. In 1971, a successor governor appointed Daniel to fill a vacancy on the Texas Supreme Court. Justice Daniel was reelected to the Court in 1972 and 1979, retiring after eight years of service during his second elected term on the Court. His son Price Daniel, Jr., also became an attorney and, ironically, a visiting professor teaching "Conflicts of Laws" at Texas Southem University's Thurgood Marshall School of Law during the 1970s. See Address by the Honorable Joe Greenhill, 4 TEXAS SO. L. REv. 179, 184 (1976-77). 
school. He doesn't have to wait to talk to a professor because he's the only one. $\mathrm{He}$ doesn't have to wait in the library because he's the only one. ${ }^{41}$ And Your Honors must not go into the area of social policy. And therefore, Your Honors, the 14th Amendment has not been violated." ${ }^{42}$

Daniel's First Assistant, Joe R. Greenhill, then argued the historical meaning of the Fourteenth Amendment. He told the Justices that the evidence shows that the framers and ratifiers had not intended it to require "mixed schools." Marshall, in rebuttal, argued that although the history of the Fourteenth Amendment could be used to support either position on school integration, its equality requirements meant equality "in its normal context," which is what Texas was denying to Sweatt. ${ }^{43}$

The Court recessed at the conclusion of the Sweatt $v$. Painter argument. Later that afternoon, John Frank took Leon Higginbotham through the brass gates that separate the public areas of the Supreme Court from the Justices' chambers and introduced him to Frank's former boss, Justice Hugo Black.

It is hard to overstate what this day and these experiences meant to young Leon Higginbotham. Seeing and hearing Thurgood Marshall in action-a first for Higginbotham-was galvanizing. "As I listened to Thurgood Marshall's articulate and forceful argument," Higginbotham wrote later,

$[\mathrm{H}] \mathrm{e}$ seemed almost superhuman. Although counsel for other appellants were excellent craftsmen, Thurgood Marshall brought an extra emotional dimension to his presentation: he supported his argument with appropriate legal scholarship, but the tone of his voice expressed controlled outrage. He seemed to be asking why, four years after black veterans like Heman Sweatt and others helped crush Hitler and Hirohito on foreign battlefields, they still had to plead for the rudimentary justice

41. A contemporaneous account of the oral argument reported that it was Thurgood Marshall who had been

sarcastic about the efforts of Texas to defend the separate law school. He pointed out that the lower courts in Texas had originally held that the basement [sic] law school in Austin was equal to that of the white University of Texas Law School. Since the new Negro law school in Houston was concededly superior to the Austin school, it must be superior to the school for white students, he concluded.

Will Maslow, Summary of Argument before United States Supreme Court in Segregation Cases on April 3 and 4, 1950, CLSA REPORTS (Commission on Law and Social Action of the American Jewish Congress, Apr. 5, 1950). Maslow was a New York attorney for the AJC, which filed its own amicus brief in Sweatt. On Thursday, April 6, 1950, the NAACP's Inc. Fund received a copy of the CLSA newsletter that contained Maslow's report on the oral arguments that had occurred on Monday and Tuesday of that week. Thurgood Marshall reviewed the newsletter and made a note that it should be retained. See id., in Group II, Box B110, File: "Office Orders \& Subscriptions, 1949-50," NAACP Papers, Manuscript Division, Library of Congress, Washington, D.C. (bearing date stamp, handwritten initials "TM" and his note "File TM") (cited in TUSHNET, supra note 38, at 344 n.6).

42. ALH 1993 Alliance for Justice remarks, supra note 18, at 2.

43. Racial "Segregation" Attacked, 18 U.S.L.W. 3277, 3281 (Apr. 11, 1950). See also Russell On-line Archive, supra note 6. 
Teacher, Student, Ticket

available to other citizens without reservation. ${ }^{44}$

It was, Higginbotham explained in emotional, impromptu remarks more than forty years later, "an argument of such extraordinary eloquence that it gave me certain feelings of confidence which I needed and which I shall never forget. ${ }^{, 45}$ Marshall's argument was, to Higginbotham, an eloquent assertion of the promise of equality not only for Heman Sweatt. It was, to Higginbotham, an assertion of his own equality too.

For Leon Higginbotham, this short afternoon had turned into-and it always remained-one of the most moving, defining moments of his life. As he walked out onto the plaza in front of the Court on that sunny, very warm afternoon, ${ }^{46}$ Higginbotham literally looked upwards. He read the inscription "Equal Justice Under Law" above the Court's pillars. And he believed. He believed, having just seen it happen, that an advocate could pursue great causes. He believed that Thurgood Marshall and the NAACP would succeed in their efforts to make equal justice a reality for all Americans. And Higginbotham resolved that he would become one of the lawyers who would fight to eradicate governmentally-enforced racism. ${ }^{47}$

\section{TEACHERS}

In his later telling of this story, Judge Higginbotham was always careful to identify the true protagonist, and the real hero, of April 4, 1950. It was not he, the lucky spectator. It was not McLaurin or Sweatt, the brave, pioneering litigants. Nor was it even Thurgood Marshall or another of the advocates who demanded so effectively the fundamental justice that the Constitution owed their clients. Nor was it any member of the Court that would, before summer arrived, unanimously declare that the Fourteenth Amendment was with McLaurin and Sweatt - that it prohibited the unequal treatment that each had experienced in state graduate schools. ${ }^{48}$

For Leon Higginbotham, his April 1950 afternoon at the Court was surely about all of the above, but it was primarily about John P. Frank, the teacher who got him there. In June 1993, Judge Higginbotham was pleasantly surprised to find that John Frank-who Higginbotham had earlier called "one of

44. ALH 1991 Marshall Tribute, supra note 18, at 60.

45. ALH 1993 Alliance for Justice remarks, supra note 18, at 1.

46. The weather was balmy, the noon sky was sunny, and the high temperature that afternoon was eighty degrees. See WASH. POST, Apr. 5, 1950, at 1A (high temperature), 1B (weather description and photographs of "Government girls" eating their lunches outdoors and tourists admiring cherry blossoms along the Tidal Basin).

47. See ALH 1991 Marshall Tribute, supra note 18, at 60; ALH 1993 Alliance for Justice remarks, supra note 18 , at 2 .

48. See McLaurin v. Oklahoma State Regents for Higher Educ., 339 U.S. 637 (1950); Sweatt v. Painter, 339 U.S. 629 (1950). In Sweatt, the Court's analysis seems to have been strongly influenced by the views of amicus curiae the Committee of Law Teachers Against Segregation in Legal Education. See Jonathan L. Entin, supra note 6, at 61-63. 
the most sensitive professors I met on the issue of race relations" 49 - had been recruited to introduce him to a large crowd that was honoring him with an award. Higginbotham shared his memories of the April 1950 trip to the Supreme Court and described his friend as follows:

Professor Frank will always be my professor.... But what was really critical was that he took me seriously....

We had people in our class who were grandchildren of Supreme Court Justices, who were children of Supreme Court Justices, individuals who were Rockefellers, who had power and influence-and John took me in. And I think he helped make me a far better lawyer than I otherwise ever would have been. ${ }^{50}$

Leon Higginbotham did, of course, become a teacher in addition to being a lawyer. He did his teaching in the formal sense of holding adjunct faculty positions at numerous schools while he was a sitting judge, and in his fulltime position at Harvard following his "retirement." He really was a teacher, however, in all of his pursuits, including his judging, his research and writing, his constant speechmaking, and his close relationships with colleagues, law clerks, research associates, interns, and pals.

Here is the connection, in Judge Higginbotham's words, to a warm afternoon in 1950 Washington, D.C.:

[T] he opportunity that John [Frank] gave me was very important- I've always felt in my days of teaching that I respect the John Franks.

... And if I transmit anything to the many law clerks I see here-all of you know I respect you and love you and admire you as students-it is partially because of the legacy I got at Yale and some extraordinarily wonderful people I met there who gave me confidence that the pursuit of justice is not an inappropriate profession for a lawyer. ${ }^{51}$

Leon Higginbotham taught from a baseline of deep academic expertise: he studied intensively, thought deeply, produced striking and voluminous scholarship, designed important courses, and presented material to students in a dynamic, engaging fashion.

Leon Higginbotham the teacher was much more, however, than very good by these traditional measures. He was great to his students, and in ways that resemble quite strikingly what Professor Frank was to and for Leon when he was a young law student. Judge Higginbotham taught his substantive views of justice by living them. He was available to his "students," broadly defined, almost without limitation. He was committed to learning about them as people. He was interested in them as individuals. He had an eye for their full potential and an abiding interest in their advancement and full development-toward the goals they were seeking, and also toward the goals and destinations that were

49. A. Leon Higginbotham, Jr., Book Review, 122 U. PA. L. REV. 1044, 1052 n.42 (1974) (reviewing DERRICK A. BELL, RACE, RACISM \& AMERICAN LAW (1973)).

50. ALH 1993 Alliance for Justice remarks, supra note 18, at 2.

51. Id. 
well beyond their current visions and horizons. He had an instinct to reach out on their behalves, to use-to risk-his stature, ideas, and connections for them. He had an urge to invite them, or just to take them, along to see people they could not have gotten near and places they could not have crashed without him. ${ }^{52}$ And he had the habit of opening his own wallet to make a lot of that happen.

For teachers - for the academy, and particularly for Leon Higginbotham's legal academy - that should be a continuing challenge. The role model that he had in John Frank became the role model that Judge Higginbotham was. Even today, through the history of his life, his spoken words and his scholarly writings, A. Leon Higginbotham, Jr. can still be a role model for anyone who is motivated to be his student.

Judge Higginbotham would, of course, deny, or at least minimize, this grand description of himself and his legacy. And he would be, in doing so, genuine-he was a man of great talents and accomplishments, and he had high ambitions, but he was, at his core, truly a modest person who preferred to focus on others rather than himself. He would, I believe, turn this consideration of him as a teacher in his maturity back to a consideration of him as a student in his youth. He would, in short, return the focus to Professor John Frank.

John Frank, still very sharp at age 84 , takes an interestingly similar approach. In our recent conversations about the April 1950 trip to the Supreme Court (which he candidly admits to recalling only in a general way), Mr. Frank sincerely minimizes his own role. He talks of his dear friend Leon and reproaches himself, in a way that Leon Higginbotham surely would call unjustified, for not having fully recognized how poor Leon was as a law student, ${ }^{53}$ for not having bought him more meals, for not having fed him in the Frank home more often, for doing less than everything one could for another person.

That is, respectfully, much too tough an assessment of one teacher's, and even one friend's, capacity and duty to another person. The fairer standardthe one that Leon Higginbotham employed when he so often recalled what John Frank and other Yale law professors did do for him $^{54}$-is to recognize, and emulate, the teachers who make the effort. And John Frank, when he thinks about the ticket he bought for Leon Higginbotham and the doors he took him through on April 4, 1950, knows this. "It was," John Frank said recently, "really just a trifling thing. But not to him.", 55

52. See, e.g., Colleen L. Adams, Rubin M. Sinins \& Linda Y. Yueh, A Life Well-Lived: Remembrances of Judge A. Leon Higginbotham, Jr.-His Days, His Jurisprudence, and His Legacy, 33 LoY. L.A. L. REV. 987,991 n.19 \& 1005-06 nn. 76-78 (2000).

53. See supra note 19 and accompanying text.

54. See A. Leon Higginbotham, Jr., supra note 19, at 27 (naming Boris Bittker, Charles Clark, Tom Emerson, John Frank, Myres McDougal, and Wesley Sturges as teachers who "gave me dignity [and] I loved them for it").

55. Telephone Interview with John P. Frank (Jan. 24, 2002). 
